\title{
Innovation attributes and their linkages to behavioral drivers of farmers' intention to adopt True Shallot Seed
}

\author{
Witono Adiyoga* \\ Indonesian Vegetable Research Institute, Jl. Tangkuban Perahu 517, Lembang, Bandung - 40391, \\ West Java, Indonesia.
}

\begin{abstract}
True Shallot Seed (TSS) has been promoted as an alternative solution to overcome shallot yield problems in Indonesia. A case study method was employed to assess perceptions of innovation attributes and their linkages to behavioral drivers of farmers' intention to adopt TSS. Respondents were shallot farmers in Cirebon and Brebes involved in participatory on-farm trials. All innovation attributes, i.e. relative advantage, compatibility, complexity, triability and observability are perceived as positive by farmers. Farmers' attitudes toward TSS suggest a favorable evaluation of TSS innovation. Concerning subjective norms, farmers believe that researchers/extension workers encourage their behavior to adopt TSS. In terms of behavioral control, farmers perceive the ease of performing TSS adoption. Meanwhile, farmers also indicate a high intention to perform the behavior of adopting TSS. This pre-adoption case study has generated some hypotheses for further detailed examination and test. Those hypotheses address important research needs, such as understanding TSS innovation attributes as perceived by farmers, the antecedents of farmers' attitudes toward TSS, and the role of farmers' behavioral preferences toward intentions to adopt TSS. It is recommended to integrate the innovation diffusion theory with the theory of planned behavior as the framework for future adoption studies using survey research method.
\end{abstract}

\section{Introduction}

Time series data analysis of 1970-2019 indicates positive average growth rates per year of production $(4.07 \%)$, harvested area $(2.98 \%)$ and yield $(1.09 \%)$ that still suggest an increasing trend of shallot production in Indonesia. However, the average national shallot yield growth rate in the last two decades $(2000-2009=0.10 \%$ and $2010-2019=0.36 \%)$ showed a significant decrease compared to the previous ten-year periods $(1990-1999=$ $2.41 \%$ ) [1]. The yield growth rate decline is quite alarming since it may indicate symptoms of stagnation in the yield of shallots in Indonesia [2,3]. Meanwhile, some studies suggest that shallot production costs per hectare are continuously increasing from year to year $[4$,

\footnotetext{
${ }^{*}$ Corresponding author: adiyogawitono@gmail.com
} 
5]. The combination between yield stagnation and costs increase will most probably affect both farmers (producers) and consumers in short/medium term. When shallot farming is becoming less financially appealing, farmers will undoubtedly start to lose their interest of growing this crop. In this situation, farmers may continue to carry out their production activities, if there is an incentive in product prices that can compensate for the increase in costs. However, an increase in product prices will in turn create additional burdens for consumers. Therefore, continuing to make improvements to crop yield, in this case for shallot, is necessary to ensure improved satisfaction for both producers and consumers [6].

New agricultural technologies, such as high-yielding crop varieties, has been recognized as an innovation that offers the promise of improving productivity and hence the welfare of both producers and consumers [7, 8]. True Shallot Seed (TSS) is one of the agricultural innovations with great potential to be used as an alternative to seeds from tubers/bulbs - planting material commonly used by shallot farmers $[9,10]$. Besides having higher yield potential as compared to shallots from bulb-seeds, the seed of true shallots also has the following advantages: (a) not bulky, (b) less-expensive, (c) long-term shelf life, (d) relatively virus-free, and (e) produces bigger bulb size [11]. These have prompted researchers to intensify studies that include improvements in seedling technique [12, 13], after transplanting seedling performance $[14,15]$, and mini-tuber production techniques $[16,17]$. Those studies basically conclude that the use of TSS is technically feasible. TSS innovation has also received a fairly positive response at the farmers' level $[18,19]$. However, some preliminary studies $[20,21]$ suggest that the rate of TSS adoption at the national level is still quite low.

Technological change from the adoption of new technologies is the main driver of the strategies for increasing agricultural productivity and promoting agriculture development [22]. Agricultural innovation is often actualized as new or improved existing technical package of technologies brought into use in a specific context in order to increase effectiveness and competitiveness, with their adoption as the main indicator for measuring successes and impacts. The low adoption of TTS innovation may be acknowledged as one potential explanation for stagnating growth which threaten the target achievement of increasing national shallot production. Since shallot sub-sector progresses technologically as farmers adopt innovations, then it is very important to develop a thorough understanding of this research domain and the themes it encapsulates [23].

Over the years, studies have been carried out to reveal various explanations regarding questions related to agricultural innovation and adoption $[24,25]$. In the case of adoption, given lack or incomplete information, farmers assess the innovations based on their knowledge and experience and use them to make their choice. Farmers will come to their decisions based on their perceptions of the innovations and various constraints they confront themselves. When farmers perceive that an innovation exposes them to riskier situation and does not provide advantages over the current situation, this may most likely end up with non-adoption. When farmers perceive that an innovation is compatible to their needs and environment, and consider it as a positive investment, they will most likely adopt it. Farmer perceptions are key and intrinsic factors that significantly influence the decision process for adoption of innovation [26, 27].

Characteristic of a technology or attribute of an innovation is a precondition for adoption. In adoption decision process, farmers' subjective preferences for innovation attributes are very important to be considered. Furthermore, farmers' decisions to adopt are influenced by dynamic interaction between technology characteristics and various conditions and circumstances around them. [28, 29]. In the Innovation Diffusion Theory (IDT) [30], innovation is often depicted as a technology package and the input of a diffusion process. The process proposes five innovation attributes or characteristics i. e. 
relative advantage, compatibility, complexity, trialability and observability that shape the rate and likelihood of adoption.

Some of these characteristics are inherent to the innovation, while others concern the adopters and their usage of the innovation. However, it should be noted that the adoption decision making process is not only influenced by extrinsic variables, such as characteristic of innovation, but also by intrinsic variables, such as attitude, subjective norm and perceived behavioral control. In turn, these three variables will drive the behavioral intention as thoroughly elaborated in the Theory of Planned Behavior (TPB) [31]. Since the adoption is a very complex process, an analytical framework that combines IDT and TPB is expected to provide more insights of both relationships among extrinsic variables and processes that may shape intrinsic variables.

The theory of perceived attributes has been extensively used in both agricultural [ 32 , $33,34]$ and non-agricultural studies [35, 36]. Meanwhile, some studies examining the impact of intrinsic variables on the intentional characteristics toward innovation adoption have been also widely carried out $[37,38,39]$. Previous indication of TSS low adoption suggests that there is a need for insights elaboration on issues that are still not fully resolved in the TSS innovation diffusion. The objective of the present paper is to examine farmers' perceptions toward TSS innovation characteristics and their links to behavioral drivers of intention to adopt TSS.

\section{Methods}

A case study research method was employed to assess farmers' perceptions of TSS innovation attributes and explore farmers' attitudes towards the use of TSS in shallot cultivation. Data were collected from interviews with 3 (three) farmers from Cirebon, West Java and 5 (five) farmers from Brebes, Central Java, representing the biggest shallot producing area in Indonesia. Respondents were selected purposively based on the criteria that they were willing to participate in on-farm TSS cultivation participatory research coordinated by the Indonesian Vegetable Research Institute (IVEGRI). Those farmers were asked to set aside a small part of their traditional shallot (bulb-seed) farm for growing TSS. TSS was cultivated using transplanting method side by side with their bulb-seed crop.

Previous studies suggest that farmers are hesitate or even not interested to grow TSS if they have to produce seedlings by themselves. Therefore in this participatory trial, farmers were set to cultivate TSS under the assumption that they purchased the seedlings from seedling grower (supplied). Nevertheless, farmers were invited to the nursery three times (sowing, growing and harvesting stage) to observe and learn about seedling raising. Meanwhile, from transplanting to harvesting, TSS cultivation practices/techniques were handed over to farmers, since after transplanting stage the cultivation practices were quite similar to shallot bulb-seed cultivation.

After harvesting their TSS crop, each farmer was interviewed by using a structured questionnaire. A total of 60 statements (items) were included to cover areas related to farmers' perceptions of TSS innovation attributes and behavioral factors (attitudes, subjective norms, perceived behavioral control, and intention) towards the use of TSS. A step-by-step procedure of Likert's summated ratings was followed to develop a standardized attitude scale. Each farmer was asked to respond to each item according to their perceived attitude intensity towards the items on five point continuum (for example: 1 = strongly disagree; 2 = disagree; $3=$ undecided; 4 = agree; and $5=$ strongly agree). 


\section{Results and Discussions}

\subsection{Results}

\subsubsection{Respondent's characteristics}

In average, the respondents are of medium age with the youngest farmer being 28 and the oldest one is 61 years old. Five farmers complete elementary school, two farmers finish middle school, and only one farmer gets a high-school degree. The farm holding size is quite small averaging of $3650 \mathrm{~m} 2$. All farmers grow shallots on rented lands. The farms are mostly operated by the farmer himself with some helps from one other household member. Experience in growing shallots varies, averaging of 13.5 years. Six out of eight farmers join farmer-group. All farmers have been exposed to short training or extension of shallot cultivation using bulb seeds. Even though all farmers have not received a formal training on TSS cultivation, six of them suggest that they have participated in TSS dissemination activities, such as a field-day carried out by IVEGRI or seed private companies. Only one farmer has an experience of cultivating TSS more than once. In the meantime, the other seven farmers have only tried TSS while participating in the IVEGRI's on-farm field trial.

\subsubsection{Farmers' perceptions of TSS innovation attributes}

Cronbach's alpha scores are used to establish whether the items on the questionnaire all reliably measure the same construct (innovation attributes, made up of multiple Likert-type scales and items). The coefficient are ranging from 0.713 to 0.938 , indicating good consistency of responses [40]. These scores provide strong support for the reliability of the questionnaire, which are key properties for future cross-sectional applications of the instrument when assessing farmers' perceptions of innovation attributes.

Table 1. Cronbach's alpha scores on TSS innovation attributes

\begin{tabular}{|c|l|c|c|l|}
\hline No & \multicolumn{1}{|c|}{ Attribute } & Number of Items & Cronbach's alpha score & \multicolumn{1}{|c|}{ Reliability } \\
\hline 1. & Relative advantage & 8 & 0.856 & highly reliable \\
\hline 2. & Compatibility & 6 & 0.886 & highly reliable \\
\hline 3. & Complexity & 4 & 0.938 & very highly reliable \\
\hline 4. & Triability & 4 & 0.713 & highly reliable \\
\hline 5. & Observability & 3 & 0.753 & highly reliable \\
\hline
\end{tabular}

\section{Relative advantage}

Table 2. Relative advantage's mean score and standard deviation

\begin{tabular}{|l|c|c|}
\hline \multicolumn{1}{|c|}{ Items } & Mean & $\begin{array}{c}\text { Standard } \\
\text { Deviation }\end{array}$ \\
\hline Cultivation using TSS is more profitable than cultivation using bulbs & 3.25 & 1.04 \\
\hline The cost of cultivation using TSS is lower than cultivation using bulbs & 2.63 & 0.74 \\
\hline The seed cost for using TSS is lower than cultivation using bulbs & 3.63 & 1.06 \\
\hline Required chemical material is lower for TSS compared to using bulbs & 3.00 & 0.53 \\
\hline Labor cost for using TSS is lower than cultivation using bulbs & 2.38 & 0.52 \\
\hline The risk of production failure for TSS is lower than using bulbs & 2.50 & 0.53 \\
\hline $\begin{array}{l}\text { Cultivating TSS is socially more prestigious than cultivation using } \\
\text { bulbs }\end{array}$ & 4.63 & 0.52 \\
\hline Cultivating TSS provides more immediate monetary results than bulbs & 3.13 & 0.83 \\
\hline
\end{tabular}


As compared to traditional shallot production, most farmers agree that TSS production is more profitable and less seed costly (Table 2). Farmers also consider TSS production is more prestigious probably because not many farmers practice or adopt this innovation yet. However, more farmers seem to disagree that TSS production is less costly, less laborious and less risky. Meanwhile, in terms of required fertilizers and pesticides, and providing more immediate monetary results (better cash-flow), farmers tend to have indifferent perceptions (neutral). With the mean score of the total items of 3.14, it seems that farmers perceive shallot cultivation using TSS as barely more profitable as using seed bulbs.

\section{Compatibility}

Most farmers seem to be in agreement with all aspects of TSS production compatibility (Table 3). Nevertheless, regarding the possibility that the use of TSS can solve some issues of excessive use of chemicals, farmers perceive it as neutral or indifferent. The total items' mean score of 3.94 suggests that farmers perceive TSS innovation as consistent with their values, experiences and needs.

Table 3. Compatibility's mean score and standard deviation

\begin{tabular}{|l|c|c|}
\hline \multicolumn{1}{|c|}{ Items } & Mean & $\begin{array}{c}\text { Standard } \\
\text { Deviation }\end{array}$ \\
\hline TSS cultivation is similar to cultivation using bulb seeds & 4.00 & 0.93 \\
\hline TSS innovation is compatible with farmers' demand or needs & 3.75 & 0.89 \\
\hline TSS innovation is compatible in responding to the yield gap problems & 4.00 & 0.93 \\
\hline TSS innovation is compatible to answer chemicals excessive problems & 3.00 & 0.76 \\
\hline TSS innovation is compatible with local yearly cropping pattern & 4.13 & 0.35 \\
\hline TSS innovation is compatible with local social/cultural values & 4.75 & 0.46 \\
\hline
\end{tabular}

\section{Complexity}

Most farmers perceive that TSS technology is easily understood, not complicated, and not difficult to be learned (Table 4). However, farmers seem to be quite skeptical when asked to respond to if TSS cultivation is more practical than bulb-seed cultivation. In other words, comparing to the traditional shallot practices (bulb seeds), farmers are not yet fully convinced that TSS is more practical. This seems to be mainly because farmers are not accustomed yet to using seedlings as planting material. Overall mean score of 3.50 suggests that farmers perceive TSS cultivation is no more complex than the traditional shallot production techniques.

Table 4. Complexity's mean score and standard deviation

\begin{tabular}{|l|c|c|}
\hline \multicolumn{1}{|c|}{ Items } & Mean & Standard Deviation \\
\hline Cultural practices of TSS are easily understood to be implemented & 3.63 & 0.74 \\
\hline There is no technical complication to grow shallot using TSS & 3.50 & 0.76 \\
\hline Cultivation using TSS is more practical than using bulb seeds & 3.13 & 0.64 \\
\hline Learning about TSS cultivation is not difficult & 3.75 & 0.71 \\
\hline
\end{tabular}

\section{Trialability}

Most farmers are in agreement that TSS innovation has the potential to enable them having the opportunity of trying out TSS cultivation in small scale basis (Table 5). Perceptions regarding access to information and seeds may also allow farmers to have a small-scale trial of the new technology, and even make some modifications to meet their specific needs. In the meantime, farmers tend to disagree that the potential of having a small demoplot are enabled because of TSS low technical difficulties in field implementation. Overall mean score of 3.66 indicates a fairly good level of triability for TSS. 
Table 5. Trialability's mean score and standard deviation

\begin{tabular}{|l|c|c|}
\hline \multicolumn{1}{|c|}{ Items } & Mean & Standard Deviation \\
\hline $\begin{array}{l}\text { Once interested, farmers should have the opportunity to try out TSS } \\
\text { on limited or small-scale basis }\end{array}$ & 4.75 & 0.46 \\
\hline $\begin{array}{l}\text { TSS information is easy to obtain so that farmers are possible to } \\
\text { carry out a small scale trial }\end{array}$ & 3.88 & 1.13 \\
\hline $\begin{array}{l}\text { TSS planting materials (seeds) are readily available so that farmers } \\
\text { could try them at any time }\end{array}$ & 3.38 & 1.06 \\
\hline $\begin{array}{l}\text { TSS technical difficulty is relatively low so that farmers could easily } \\
\text { conduct a small demonstration plot }\end{array}$ & 2.63 & 0.92 \\
\hline
\end{tabular}

\section{Observability}

In terms of learning how to grow shallot using TSS, farmers agree that they can learn from observing results at neighboring farmers and share the gained knowledge to others (Table 5 ). With the overall mean score of 3.46, the observability aspects of TSS innovation seem to be perceived as positive by farmers.

Table 5. Observability's mean score and standard deviation

\begin{tabular}{|l|c|c|}
\hline \multicolumn{1}{|c|}{ Items } & Mean & Standard Deviation \\
\hline $\begin{array}{l}\text { Performance and benefit of TSS are easily observed by prospective } \\
\text { users }\end{array}$ & 3.50 & 1.07 \\
\hline TSS cultural practices are easily replicated by interested users & 3.38 & 0.74 \\
\hline $\begin{array}{l}\text { Improved understanding of TSS obtained from dissemination } \\
\text { activities are easy to be explained or passed on to other farmers }\end{array}$ & 3.50 & 0.76 \\
\hline
\end{tabular}

\subsubsection{Farmers' attitude, subjective norm, behavioral control, motivation-intention, and behavioral change towards TSS innovation}

The reliability of all items of the behavioral variables is assessed by using Cronbach's Alpha (CA) score. CA scores indicate high reliability $(0.70-0.90)$ and very high reliability $(>0.90)$ of the questionnaire. Therefore, it is very likely that the questionnaire could be reused for future studies examining those behavioral variables.

Table 6. Cronbach's alpha scores on some behavioral factors toward TSS innovation

\begin{tabular}{|c|l|c|c|l|}
\hline No & \multicolumn{1}{|c|}{ Attribute } & $\begin{array}{c}\text { Number of } \\
\text { Items }\end{array}$ & $\begin{array}{c}\text { Cronbach's } \\
\text { alpha score }\end{array}$ & \multicolumn{1}{|c|}{ Reliability } \\
\hline 1. & Attitude & 8 & 0.913 & very highly reliable \\
\hline 2. & Subjective norm & 3 & 0.744 & highly reliable \\
\hline 3. & Behavioral control & 6 & 0.890 & highly reliable \\
\hline 4. & Behavioral intention & 8 & 0.855 & highly reliable \\
\hline 5. & Behavioral change & 5 & 0.921 & very highly reliable \\
\hline
\end{tabular}

\section{Attitude}

Even though, TSS is perceived as a new technology for farmers, but they are quite open and eager to learn more since it is positively perceived as prospective (Table 7). Farmers perceive that TSS cultivation is similar to bulb-seed cultivation and it may provide higher yield and better bulb quality. Farmers also consider that TSS cultivation is more profitable even though this may slightly contradict their attitude towards the cost of TSS that suggests of being more expensive. The overall mean score of 4.00 indicates that farmers tend to have a favorable evaluation towards TSS innovation. 
Table 7. Attitude towards shallot cultivation using TSS

\begin{tabular}{|l|c|c|}
\hline \multicolumn{1}{|c|}{ Items } & Mean & $\begin{array}{c}\text { Standard } \\
\text { Deviation }\end{array}$ \\
\hline I am basically open to receiving new information/knowledge about TSS & 4.50 & 0.53 \\
\hline I want to learn more about growing shallot using TSS & 4.63 & 0.74 \\
\hline I have positive impression regarding the prospect of TSS cultivation & 4.13 & 0.64 \\
\hline I am interested to use TSS since it's cultural practices are quite similar & 3.63 & 0.52 \\
\hline In my opinion, the production cost of TSS is lower than bulb-seeds & 2.88 & 0.64 \\
\hline In my opinion, the yield of TSS is higher than bulb-seeds & 3.88 & 0.83 \\
\hline In my opinion, the TSS bulb quality is better than bulb-seeds & 4.75 & 0.46 \\
\hline In my opinion, TSS is more profitable than bulb-seed cultivation & 3.63 & 0.92 \\
\hline
\end{tabular}

\section{Subjective norm}

Most farmers believe that researchers, extension workers and farmer group may approve and encourage their behavior to adopt TSS (Table 8). However, they do not experience pressures for adopting TSS from their neighboring farmers. Overall mean score of 3.29 may relate to farmers' beliefs about whether peers and people of importance think they should engage in the behavior of adopting TSS innovation.

Table 8. Subjective norm towards shallot cultivation using TSS

\begin{tabular}{|l|c|c|}
\hline \multicolumn{1}{|c|}{ Items } & Mean & Standard \\
\hline Researchers and extension workers as sources of TSS information & 3.88 & 1.13 \\
\hline Neighboring farmers strongly encourage me to adopt TSS shallot & 2.63 & 0.92 \\
\hline The farmer group in which I join strongly encourage me to adopt TSS & 3.38 & 1.06 \\
\hline
\end{tabular}

\section{Behavioral control}

Farmers perceive that based on their own decision and true intentions, adopting TSS is easy and good for them (Table 9). Even though most of their neighboring farmers do not adopt TSS yet, this is not considered by participated farmers as one of the difficulties in enacting the behavior of adopting TSS innovation. The total items' mean score of 3.63 indicates farmers' expectation that the performance of the behavior of adopting TSS innovation is within their control.

Table 9. Behavioral control towards shallot cultivation using TSS

\begin{tabular}{|l|c|c|}
\hline \multicolumn{1}{|c|}{ Items } & Mean & $\begin{array}{c}\text { Standard } \\
\text { Deviation }\end{array}$ \\
\hline Adopting the new technology of TSS shallot cultivation is easy for me & 3.25 & 0.89 \\
\hline Adopting the new technology of TSS shallot cultivation is good for me & 3.75 & 0.46 \\
\hline I most likely plan to adopt the new TSS shallot cultivation & 4.00 & 0.93 \\
\hline TSS adoption decision is completely up to me & 4.00 & 0.53 \\
\hline Most of the farmers close to me have adopted the TSS cultivation & 2.75 & 0.46 \\
\hline I believe that if I really intend to, I can adopt TSS with no difficulties & 4.00 & 0.53 \\
\hline
\end{tabular}

\section{Behavioral intention-motivation}

Seven out of eight farmers agree that crop profitability has motivated them to grow shallot (Table 10). Farmers are also motivated to cultivate shallot because it suits their expertise and capital endowment. They are driven to cultivate shallot because it can be grown multiple times in a year and they have already saved seeds available from the last season's harvest. There are also some peers or social pressures (such as, following habitual practices and neighboring farmers) that seem to influence farmers' motivation of growing shallot. Seven out of eight farmers are in agreement that growing shallot is quite reliable for 
maintaining and improving family welfare. The overall mean score of 4.10 may suggest that these motivational factors highly influence the intention to perform the behavior of adopting TSS innovation.

Table 10. Behavioral intention towards shallot cultivation using TSS

\begin{tabular}{|l|c|c|}
\hline \multicolumn{1}{|c|}{$\begin{array}{c}\text { Items } \\
\text { (I intend to grow shallots because......................) }\end{array}$} & Mean & $\begin{array}{c}\text { Standard } \\
\text { Deviation }\end{array}$ \\
\hline it is a profitable crop & 4.13 & 0.64 \\
\hline it could be grown 3-4 times a year in the same parcel of land & 4.63 & 0.52 \\
\hline it's cultivation practices suit my expertise & 4.75 & 0.46 \\
\hline it's cultivation costs are still within my capital bracket & 4.50 & 0.53 \\
\hline it is a habitual farming practice for most farmers in the area & 4.63 & 0.52 \\
\hline following local neighboring farmers that mostly grow shallot & 4.38 & 0.52 \\
\hline already have seeds saved from previous harvest & 4.25 & 0.89 \\
\hline it's price is relatively more stable compared to other vegetable crops & 1.50 & 0.53 \\
\hline
\end{tabular}

\section{Behavioral change}

A behavioral change refers to a change in an individual's behavior when compared to previous behavior. In the context of this study, farmers' behavior of shallot cultivation using bulb-seeds changes to farmers' behavior of shallot cultivation using TSS. This study is an immediate evaluation of a dissemination activity, so it has not explored the issue of actual adoption yet, but more of the perceived potential adoption of TSS innovation. Hence, the behavior of interest (perceived potential adoption) is defined in terms of its target (practicing or planting of TSS), the context in which it occurs (participating in extension/dissemination activities), and the effort/action involved (getting information and having discussions). The overall mean score of 2.73 may suggest that the potential adoption of TSS is perceived relatively low.

Table 11. Behavioral change towards (perceived potential adoption) TSS cultivation

\begin{tabular}{|l|c|c|}
\hline \multicolumn{1}{|c|}{$\begin{array}{c}\text { Items } \\
(1=\text { never, } 2=\text { rarely, 3 = sometimes, } 4=\text { often, 5 = always })\end{array}$} & Mean & $\begin{array}{c}\text { Standard } \\
\text { Deviation }\end{array}$ \\
\hline $\begin{array}{l}\text { How often have you tried to get information about TSS shallot cultivation } \\
\text { technology? }\end{array}$ & 3.25 & 0.71 \\
\hline $\begin{array}{l}\text { How often have you participated in TSS extension activities or witnessed } \\
\text { demonstrations of TSS shallot cultivation practices? }\end{array}$ & 2.88 & 0.99 \\
\hline $\begin{array}{l}\text { How often have you discussed the TSS shallot cultivation with your } \\
\text { farmer friends or farmer groups? }\end{array}$ & 2.50 & 1.07 \\
\hline $\begin{array}{l}\text { How often have you tried (on a small scale basis) to practice TSS shallot } \\
\text { cultivation? }\end{array}$ & 2.63 & 0.92 \\
\hline How often have you planted shallots using TSS? & 2.38 & 1.06 \\
\hline
\end{tabular}

\subsection{Discussions}

Previous studies on agricultural technology adoption reveal that farmers' perceptions of the innovation's attributes could be used as important predictors of their attitudes toward adoption decisions [26, 27, 32, 34]. This study, in particular, is carried out to portray farmers' perceptions toward True Shallot Seed (TSS) innovation attributes. Since this study is a part of a dissemination activity, it only assesses perceived potential adoption, not ultimate adoption of TSS.

In this study, relative advantage refers to the degree to which TSS innovation provides desirable consequences for the farmers compared to shallot cultivation using bulb-seeds. Assuming 5.0 is the highest positive response score, the mean score of the total items of 
3.14 suggests that farmers perceive shallot cultivation using TSS as barely more profitable as using seed bulbs. In the meantime, some diffusion studies find that relative advantage is the most important trait for adoptability [41], one of the best predictors of an innovation adoption, and a decisive factor in determining adoption of an innovation [42]. Considering relative advantage has the lowest score among other attributes, it is very likely that some interventions to address the issue of TSS profitability need to be prioritized. Some actions that could be taken to increase the TSS desirability are by optimizing yield or minimizing the yield gap through the use of the best quality seeds available in the market, and by reducing the production costs, especially the cost of planting material (seedlings).

TSS innovation not only needs to be personally compatible with farmers, but also has to be compatible with the existing shallot cultivation techniques and farmers' resource endowment. The compatibility's mean score of 3.94 suggests that farmers perceive TSS innovation as quite consistent with their farming habits, expertise, experiences and their needs, especially to increase yield. In terms of compatibility, a higher propensity to adopt TSS innovation could be pushed further by continuously encouraging farmers to buy seedlings or by establishing seedling grower groups.

Concerning complexity, a more intricate and difficult innovation will confront farmers with more uncertainties that may influence their adoption decisions. Overall mean score of 3.50 suggests that farmers perceive the ease of use of the TSS innovation as no different as the traditional shallot production techniques. Based on the complexity attribute, farmers' propensity to adopt TSS could be increased by keep familiarizing them to use good healthy seedlings that have good survivability after transplanted.

Triability allows farmers experimenting with the new technology, reviewing its performance, modifying it to suit their specific needs. The ability to try an innovation may provide farmers with self-generated information that is very helpful to reduce uncertainties regarding the innovation's relative advantage and complexity. Overall mean score of 3.66 indicates a fairly good level of triability for TSS. Distributing free seed samples and short technical guidance will not only be a promotional activity, but will also provide farmers more opportunities to try TSS on small-scale basis.

Benefits and impacts of an innovation should be easily observed for it to be quickly adopted. When an innovation has observable benefits and impacts, farmers will be interested to adopt and show other colleagues what they are doing and their success stories. With the overall mean score of 3.46, the observability aspects of TSS innovation are perceived as quite positive by farmers. More observability of TSS impacts are expected by increasing the TSS dissemination activities through demonstration plots, field days, and farmer-managed on-farm trials. Based on the discussion, the following hypothesis could be proposed:

Hypothesis 1. The more profitable, understandable, compatible, observable, and testable the TSS innovation, the higher the potential for its adoption

The assessment of innovation attributes and farmers' preferences are important predictors of adoption decisions [25, 26, 39, 43]. Hence, in this framework, farmers' perceptions of TSS innovation attributes are likely to influence their behavioral preferences and these preferences will affect the TSS adoption behavior. In this case, the Innovation Diffusion Theory [30] is integrated to the Theory of Planned Behavior [31] that considers the impact of attitudes, subjective norm, and perceived behavioral control on the intentional characteristics toward the adoption of an innovation.

In this study, attitudes refer to the degree to which farmers have a favorable or unfavorable evaluation of the TSS innovation adoption. Concerning the relationship between farmers' assessments of the TSS innovation attributes and farmers' attitudes 
toward TSS, the attributes are actually similar to the attitudinal beliefs. These beliefs typically identify the advantages and disadvantages associated with adopting TSS innovation that in TPB are considered as antecedents of the attitudes. Hence, attitudes toward TSS innovation depend on subjective perceptions and farmers' cost/benefit evaluations concerning the usefulness and ease of use of adopting TSS. The overall mean score of 4.00 suggests that based on their evaluation of TSS innovation attributes, farmers incline to develop a positive attitude towards TSS innovation. Based on the discussion, the following hypothesis could be proposed:

Hypothesis 2. The more positive is farmers' assessment regarding TSS innovation attributes, the more favorable is farmers' attitudes toward TSS innovation.

TPB is widely used to examine variations in farmer behavior and identify the drivers that influence farmers' decision making process. Central to TPB is the concept of intention that reflects the extent to which individuals are motivated to perform a given behavior. In the context of this study, intention refers to the extent to which farmers are motivated to adopt TSS innovation. The overall mean score of 4.10 may suggest that some sociopsychological factors highly influence the intention of farmers to perform the behavior of adopting TSS innovation. Besides attitudes, the other two socio-psychological factors that influence intention are subjective norms, and perceived behavioral control.

Subjective norms refer to farmers' perceptions about social support to adopt TSS innovation. Overall mean score of 3.29 may relate to farmers' beliefs about the importance of significant others (researchers, extension workers and farmer group) to engage in the behavior of adopting TSS innovation. The greater the importance of an influencer as perceived by farmers, the greater the likelihood that farmers will follow the suggested behavior of adopting TSS.

Perceived behavioral control refers to the farmers' perceptions of the ease or difficulty of adopting TSS or the extent farmers think that they can actually adopt TSS innovation. The total items' mean score of 3.63 indicates farmers' expectation that adopting TSS innovation is within their control (mainly based on their own decision and true intention). The greater farmers perceive that they have control the more likely farmers will intend to adopt TSS innovation. It should be noted though that this study is carried out as an immediate evaluation of a dissemination activity, so it may only explore the perceived potential adoption, not the actual adoption of TSS. Nonetheless, based on the discussion the following hypothesis for future adoption studies could be proposed:

Hypothesis 3. The more farmers develop positive attitudes toward TSS, feel social support for adopting TSS, and perceive to have control over TSS adoption, the more likely they intend to adopt TSS and actually adopt TSS innovation.

\section{Conclusions}

Farmers perceive positively all TSS innovation attributes and tend to consider TSS of having potential as an alternative to shallot cultivation using bulb seeds. Based on their evaluation of TSS characteristics, farmers are more likely to have favorable attitudes toward TSS innovation. Farmers also believe that some significant others, such as researchers and extension workers, have encouraged and supported them to adopt TSS innovation. In terms of behavioral control, farmers perceive the ease of performing TSS adoption, since they believe of having access to resources and opportunities needed to perform such behavior. The behavioral constructs seem to have driven farmers to be highly motivated and indicate a quite strong intention to perform the behavior of adopting TSS. 
This pre-adoption case study has highlighted that there is much potential in exploring farmers' decision making process for adopting TSS innovation. From this type of exploratory work, some research questions that deal with the adoption of innovation by farmers might emerge for further elaboration in larger scale study designs. This case study has generated some hypotheses for further wider examination, review and test. Those hypotheses address some important research needs, such as understanding TSS innovation attributes as perceived by farmers, the antecedents of farmers' attitudes toward TSS, and the role of farmers' behavioral preferences toward intentions to adopt TSS. Findings of this study suggest that more insights could be gained by integrating IDT and TPB. It is recommended to employ this integrated framework for further adoption studies using survey research method to capture more generalizable, richer and more articulated explanation of farmers' adoption decision process.

\section{References}

1. Badan Pusat Statistik. Data produksi, luas panen dan produktivitas bawang merah nasional, 1970-2019. Jakarta, Indonesia (2020).

2. A.R. Yanuarti \& M.D. Afsari. Profil komoditas barang kebutuhan pokok dan barang penting - Bawang merah, Direktorat Jenderal Perdagangan Dalam Negeri Kementerian Perdagangan (2016).

3. C. Hermanto. Bawang merah: Kebutuhan, produksi, dan supply chains, teknologi produksi bawang merah saat ini dan ke depan, Materi presentasi disampaikan pada Workshop Capacity Building and TSS Technology Adoption, Ewindo, Purwakarta (2019).

4. H.F. Aldila, A. Fariyanti \& N. Tinaprilla. Analisis profitabilitas usahatani bawang merah berdasarkan musim di tiga kabupaten sentra produksi di Indonesia, SEPA, 11(2), hal. 249-260 (2015).

5. L.T.W. Astuti, A. Daryanto, Y. Syaukat \& H.K. Daryanto. Analisis resiko produksi usahatani bawang merah pada musim kering dan musim hujan di Kabupaten Brebes, Jur. Ekon. Pert. dan Agrib. (JEPA), 3(4), pp. 840-852 (2016).

6. K. Fuglie, M. Gautam, A. Goyal \& W.F. Maloney. Harvesting prosperity -Technology and productivity growth in agriculture 2020, International Bank for Reconstruction and Development/The World Bank (2020).

7. O. Adedoyin, M.N. Shamsudin, A. Radam \& I. AbdLatif. Effect of improved high yielding rice variety on farmer's productivity in Mada, Malaysia Int. J. Agric. Sci. \& Vet. Med., 4(1), pp. 38-52 (2016).

8. M. Qaim. Role of new plant breeding technologies for food security and sustainable agricultural development, App. Econ. Pers. and Pol., 42(2), pp. 129-150. doi:10.1002/ aepp.13044 (2020).

9. L. van den Brink \& R.S. Basuki. Production of True Seed Shallots in Indonesia, Acta Hort., 958, pp. 115-120 (2012).

10. A. Wulandari, D. Purnomo \& Supriyono. Potensi biji botani bawang merah (True Shallot Seed) sebagai bahan tanam budidaya bawang merah di Indonesia, EL-VIVO, 2(1), hal. 28 - 36 (2014).

11. O. Askari-Khorasgani \& M. Pessarakli. Agricultural management and environmental requirements for production of true shallot seeds - A review, Adv. in Plants \& Agric. Res., 9(2), pp. 318-322 (2019). 
12. G.A. Sopha, N. Sumarni, W. Setiawati \& Suwandi. Teknik penyemaian benih True Shallot Seed untuk produksi bibit dan umbi mini bawang merah, J. Hort. 25(4), hal. 318-330 (2015).

13. I.G.A.M.S. Agung \& J.W. Diara. Pre-sowing treatment enhanced germination and vigour of True Shallot (Allium cepa var. aggregatum), Seeds, Int. J. of Envir., Agric. and Biotech. (IJEAB), 2(6), pp. 3262-3267 (2017).

14. S. Swastika, R. Yusuf \& I. N. Istina. Development prospect of shallot from true shallot seed as planting material based on land suitability in Kampar regency, Riau province. Proceeding of Innovation of Environmental-Friendly Agricultural Technology Supporting Sustainable Food Self-Sufficiency, September 18th-20 ${ }^{\text {th }}$, Surakarta, Indonesia, ISBN 978-602-344-252-2, DOI: 10.5281/ zenodo.3345882 (2018).

15. N. Sumarni. Respons tanaman bawang merah asal biji True Shallot Seeds terhadap kerapatan tanaman pada musim hujan, J. Hort., 22(1), hal. 45-52 (2012).

16. R. Rosliani, Y. Hilman, I.M. Hidayat \& I. Sulastrini. Teknik produksi umbi mini bawang merah asal biji (True Shallot Seed) dengan jenis media tanam dan dosis NPK yang tepat di dataran rendah, J. Hort., 24(3), hal. 239-248 (2014).

17. N. Khoyriyah, T. Ekowati \& S. Anwar. Strategi pengembangan umbi mini bawang merah True Shallot Seed di Kabupaten Grobogan, Jur. Ekon. Pert. dan Agrib. (JEPA), 3(2), hal. 278-293 (2019).

18. P.R. Pratiwi, S.I. Santoso \& W. Roessali. Tingkat adopsi teknologi True Shallot Seed di Kecamatan Klambu, Kabupaten Grobogan, AGRARIS: J. of Agrib. and Rur. Dev. Res., 4(1), hal. 8-19 (2018).

19. W. Roessali, E.D. Purbajanti \& T. Dalmiyatun. The adoption behaviour and its influenced factors of true shallot seed technology in Central Java, IOP Conference Series: Earth and Environmental Science, 250(1). doi: 10.1088/1755-1315/250/ 1/012072 (2019).

20. W. Adiyoga, R. Rosliani, A. Sembiring, N. Khaririyatun dan M. Prathama. Analisis sosial-ekonomi dan perilaku petani dalam pengambilan keputusan adopsi inovasi bawang merah asal biji botani (TSS), Laporan Penelitian APBN Th. 2019/No. 1804.208.053.A.3, Balai Penelitian Tanaman Sayuran (2019).

21. B. Sayaka, S.M. Pasaribu, S. Kristiantoadi. Prospect for farmers' adoption of True Shallot Seed, For. Penel. Agro Ekon., 38(1), pp. 53-66 DOI: http://dx.doi.org/ 10.21082/fae.v38n1.2020.53-66 (2020).

22. P. Karolina \& M. Kołodziejczak. The role of agriculture in ensuring food security in developing countries: Considerations in the context of the problem of sustainable food production, Sustainability, 12, 5488; doi:10.3390/su12135488, pp. 1-20 (2020).

23. K. Ogundari \& O.D. Bolarinwa. Impact of agricultural innovation adoption: a metaanalysis, Aust J. of Agric. and Res. Econ., 59, pp. 1-20 (2018).

24. S. Yokamo. Adoption of improved agricultural technologies in developing countries: Literature review, Int. J. of Food Sci. and Agric., 4(2), pp. 183-190 (2020).

25. O. Montes de Oca Munguia, D.J. Pannell \& R. Llewellyn. Understanding the adoption of innovations in agriculture: A review of selected conceptual models, Agronomy, 11, 139. https:// doi.org/10.3390/agronomy1101013 (2021).

26. C. Roussy, A. Ridier \& K. Chaib. Farmers' innovation adoption behavior: Role of perceptions and preferences, Int. J. of Agric. Res., Gov. and Ecol., 13 (2), pp.138-161 DOI: 10.1504/ IJARGE. 2017. 086439 (2017). 
27. K.A. Mottaleb. Perception and adoption of a new agricultural technology: Evidence from a developing country, Tech. in Soc. 55, pp. 126-135 (2018).

28. B.W. Feyisa. Determinants of agricultural technology adoption in Ethiopia: A metaanalysis, Cogent Food \& Agric., 6(1), 1855817, DOI: 10.1080/23311932. 2020. 1855817 (2020).

29. M. Mwangi \& S. Kariuki. Factors determining adoption of new agricultural technology by smallholder farmers in developing countries, J. of Econ. and Sust. Dev., 6(5), pp. 208-216 (2015).

30. E.M. Rogers. Diffusion of Innovations, Fifth edition, New York: Free Press (2003).

31. J. Sok, J. R. Borges, P. Schmidt \& I. Ajzen Farmer behaviour as reasoned action: A critical review of research with the Theory of Planned Behaviour. J of Agric Econ., 72(2), pp. 388-412. doi: 10.1111/1477-9552. 12408 (2021).

32. S. Mannan, S. Md. Nordin, \& S.R. Galea. Influence of innovation attributes and communication channels on new fertilizer technology adoption by paddy farmers, Aust. J. of Basic and App. Sci., 9(19), pp. 109-117 (2015).

33. D. Gandasari, Dayat, D. Dwidienawati, \& L.S. Wahyuni. Analysis of innovation attributes in the innovation adoption of agricultural mechanization technology in farmers, J. of Dev. Comm., 19(1), pp. 38-51 (2020).

34. L. Zamzami, A. Sugiyatno, \& Harwanto. Innovation characteristics and adoption opportunity of Bujangseta technology for tangerine farming, Caraka Tani: J. of Sust. Agric., 36(1), pp. 144-154 (2021).

35. H.A. Tanye. Perceived attributes of innovation: Perceived security as an additional attribute to Roger's diffusion of innovation theory, Int. J. of Multicultural and Multireligious Understanding (IJMMU), 3(6), pp. 6-18 (2016).

36. G. Vagnani \& L. Volpe. Innovation attributes and managers' decisions about the adoption of innovations in organizations: A meta-analytical review, Int. J. of Innov. Stu., 1, pp. 107-133 (2017).

37. S.B. Ja'far, A. Abdullah, M.I.A. Dagong, M. Azhar, S. Sohrah. Effect of attitude, subjective norm and behavior control on technology adoption rate of goat farmer, Adv. in Envir. Biol., 11(12), pp. 26-30 (2017).

38. J. Wang, M. Chu, C. Yang, H. Lam \& J. Tang. Determinants of pesticide application: An empirical analysis with Theory of Planned Behavior, China Agric. Econ. Rev., 10(4), pp. 608-625. https://doi.org/10.1108/CAER-02-2017-0030 (2018).

39. N.C. Akyüz \& L. Theuvsen. The impact of behavioral drivers on adoption of sustainable agricultural practices: The case of organic farming in Turkey, Sustainability, 12, 6875; doi:10.3390/su12176875, pp. 1-20 (2020).

40. M. Bujar, N. McAuslane, S. Walker \& S. Salek. The reliability and relevance of a quality of decision making instrument, Quality of Decision Making Orientation Scheme for use during the life cycle of medicines, Front. Pharmacol., 10(17) (2019)

41. R.J. Farquharson, R.J. Martin, F. Scott, C. Phaloeun, H. Sophors, S. Sinath, C. Monida, S. Sinarong \& B. Sokun. Characteristics of an agricultural innovation and incentives for adoption: Rhizobium in Cambodia, Int. J. of Envir. and Rur. Dev., 4(2), pp. 44-49 (2013).

42. A.J. Lamm, L.A. Warner, M.R. Taylor, E.T. Martin, S. White \& P. Fisher, P. Diffusing water conservation and treatment technologies to nursery and greenhouse growers. J. of Int. Agric. and Ext. Educ., 24(1), pp. 105-119. doi: 10.5191/jiaee.2017.24110 (2017) 
43. J.J. Hyland, K. Heanue, J. McKillop, E. Micha. Factors underlying farmers' intentions to adopt best practices: The case of paddock based grazing systems, Agric. Syst., 162. pp. 97-106. (2018). 